\title{
Health Risk Assessment after Exposure to Aluminium in Drinking Water between Two Different Villages
}

\author{
M. S. Qaiyum ${ }^{1}$, M. S. Shaharudin ${ }^{1}$, A. I. Syazwan ${ }^{1 *}$, A. Muhaimin ${ }^{2}$ \\ ${ }^{1}$ Environmental and Occupational Health Science Unit, Department of Community Health, \\ Faculty of Medicine and Health Sciences, Universiti Putra Malaysia, Selangor, Malaysia \\ ${ }^{2}$ Department of Environmental Management, Faculty of Environmental Studies, \\ Universiti Putra Malaysia, Selangor, Malaysia \\ E-mail: syazwan@medic.upm.edu.my \\ Received November 7, 2010; revised January 5, 2011; accepted February 18, 2011
}

\begin{abstract}
A cross-sectional study was conducted at Mukim Parit Lubok (MPL) and Parit Raja (PR), Batu Pahat, Malaysia. The main objective of this study was to determine the aluminium concentration in drinking water and to perform health risk assessment prediction among respondents from these two residential areas. A total of 100 respondents were selected from the study areas based on inclusive and exclusive criteria. Two duplicates of treated water samples were taken from each respondent's house using $200 \mathrm{~mL}$ high-density polyethylene (HDPE) bottles and $0.4 \mathrm{~mL}(69 \%)$ pure concentrated nitric acid were added as a preservative. Aluminium concentrations were analyzed using a Lambda $25 \mathrm{UV} / \mathrm{V}$ spectrophotometer. The result showed that aluminium concentration in drinking water from MPL was $0.18 \pm 0.022 \mathrm{mg} / \mathrm{L}$ and $0.22 \pm 0.044 \mathrm{mg} / \mathrm{L}$ for PR. Statistical analysis showed that 14 (28\%) water samples collected from MPL and 35 (70\%) from PR recorded concentration of aluminium above the standard limit set by the Ministry of Health, Malaysia for drinking water guideline $(0.2 \mathrm{mg} / \mathrm{L})$. The mean value of Chronic Daily Intake (CDI) of aluminium in drinking water from PR $(0.00707 \mathrm{mg} / \mathrm{kg} /$ day $)$ was significantly higher compared to MPL $(0.00164 \mathrm{mg} / \mathrm{kg} /$ day $)$. Hazard Index (HI) calculation showed that all respondents had "HI" of less than 1. In conclusion, there was an unlikely potential for adverse health effects from aluminium intake in drinking water from both study areas. However, it was necessary for some actions to be taken in order to reduce aluminium levels found in drinking water for both locations.
\end{abstract}

Keywords: Aluminium, Drinking Water, Health Risk Assessment, Chronic Daily Intake (CDI), Hazard Index (HI)

\section{Introduction}

Water is of major importance to all living things, in some organisms, up to $90 \%$ of their body weight comes from water and up to $60 \%$ of the human body is water [1]. Malaysia has an abundant water resources and adequate rainfall and yet this nation has water shortages and water quality problem $[2,27]$. A national monitoring network was established in 1978 by the Department of Environment to monitor river quality and detect changes in water quality as a result of development [2]. A study by Calderon in year 2000 has identified a number of chemical contaminants in drinking water and one of those contaminants is aluminium [3]. According to Malaysia Drinking Water Quality 2009, the permissible level of aluminium in drinking water must not exceed $0.2 \mathrm{mg} / \mathrm{L}$ [4]. Based on the Report of Study on Water Supply System 2005 that was done on two water treatment plants (WTPs) in Batu Pahat (Parit Raja IV WTP and Sri Gading WTP), there have been violations of water quality standard for aluminium levels [5]. There were 8 sampling stations from the Parit Raja IV WTP that showed violation of aluminium standard along the reticulation system with the highest value of $8.00 \mathrm{mg} / \mathrm{L}$ [5].

Aluminium can be either beneficial or harmful, depending on a number of factors, including the amounts to which someone being exposed. Aluminium is the most abundant metal and the third most abundant element, after oxygen and silicon, in the earth's crust [6]. It is widely distributed 
and constitutes approximately $8.8 \%$ of the earth's crust or approximately 88000 parts of aluminium per million parts of the earth's crust [7]. Dissolved aluminium concentrations in waters with near-neutral $\mathrm{pH}$ values usually range from 0.001 to $0.05 \mathrm{mg} / \mathrm{L}$ but rise to $0.5-1 \mathrm{mg} / \mathrm{L}$ in more acidic waters or water rich in organic matter [8]. Although acute exposure to high doses of aluminium are well tolerated, aluminium may be a contributing factor in certain neurodegenerative diseases such as Alzheimer's disease (AD), amyotrophic lateral sclerosis (ALS) and Parkinson's Dementia [9]. Aluminium levels in drinking water vary according to the levels found in the source water and whether aluminium coagulants are used during water treatment [8]. Aluminium salts such as aluminium sulphate $\left(\mathrm{Al}_{2} \mathrm{SO}_{4}\right)$ are widely used in water treatment plant as coagulants to reduce organic matter, colour, turbidity and microorganism levels in untreated water [8].

There is considerable concern throughout the world over the levels of aluminium found in drinking water sources (raw water) and treated drinking water [10]. Then, in a study, it was found out that high aluminium levels in drinking water $(\geq 0.1 \mathrm{mg} / \mathrm{L})$ were associated with an elevated risk of dementia and Alzheimer's disease [11]. Although there has been debate regarding relation of aluminium and Alzheimer Disease (AD), there were eighteen drinking water studies that have linked aluminium level to elevated risks of $\mathrm{AD}$ and elderly cognitive impairment [12].

Total removal of harmful pollutants from the environment is impossible or infeasible and many natural occurring substances such as aluminium itself also pose health risks [13]. Besides that, it has been hypothesised that aluminium exposure is a risk factor for the development or acceleration of onset of $\mathrm{AD}$ in humans [8]. Therefore, health risk assessment is used to estimate whether current exposure will pose health risks to the community studied $[13,26]$.

In this study, water samples will be taken from respondents' houses to determine their daily intake of aluminium from drinking water. In addition, water sources for both areas are different because it involves two villages with different water treatment plants, therefore comparison of aluminium levels between two different populations can be done and then compared to permissible level from Malaysia National Standard for Drinking Water Quality (2009) [4].

\section{Methods and Materials}

\subsection{Subject Recruiting and Selection of Study Locations}

A cross sectional study was conducted involving 100 respondents from two villages in state of Johor in Peninsu- lar Malaysia, namely Mukim Parit Lubok (MPL) and Parit Raja (PR). These two specific locations were selected due to non-compliance in aluminium levels in drinking water. This study were aimed at determining health risk from intake of aluminium in drinking water and the risk associate with the aluminium exposure using chronic daily intake estimation. The respondents were purposively selected from each village based on identified inclusive criteria, such as exclusive use of tap water and has lived in the village for at least 6 months. On the other hand, the exclusive criteria include consumption of other sources of drinking water such as bottled water and the usage of a water filter.

\subsection{Questionnaires and Body Weight}

A set of structured questionnaires were used in this study which comprised of two sections. The first section contained questions regarding respondents' background data such as age, household income, duration of residence and education level. The second section contained questions regarding exposure duration, chronic daily intake and water consumption during living period in the selected villages. The second section of the questionnaire was modified from the Baseline, Descriptive and Time-Activity Questionnaires used in the National Human Exposure Assessment Survey (NHEXAS)-Arizona study [14]. During the data collection period, the respondents were interviewed face to face with the researcher at their respective houses. In determining the chronic daily intake, body weight measurement was taken using a Tanita Digital Weight Scale.

\subsection{Analysis of Aluminium in Drinking Water}

Drinking water samples were collected at the respondents' kitchen tap. The tap was turned on and water was left to run for 3-5 minutes. A 200 milliliter (mL) nonacidified high-density polyethylene (HDPE) bottle was used for water sample collection. Two replicates of water samples were taken from each respondent's house. The samples were then preserved using $0.4 \mathrm{~mL} 69 \%$ pure concentrated nitric acid before being analyzed at the laboratory to ensure bacterial removal from the samples and to lengthen the storage time of the samples [15].

\subsection{Estimation of Health Risk Associated with Aluminium Drinking Water}

In order to estimate health risk associated with aluminium in drinking water, chronic daily intake (CDI) where calculated first using the following equation [17]:

$$
\operatorname{CDI}(\mathrm{I})=\left(\mathrm{C}_{1} \mathrm{R}_{1} \mathrm{~F}_{\mathrm{E}} \mathrm{D}_{\mathrm{t}}\right) /\left(\mathrm{W}_{\mathrm{B}} \mathrm{T}_{\mathrm{AVG}}\right)
$$


Where CDI (I) wasthe chronic daily intake $(\mathrm{mg} / \mathrm{kg} / \mathrm{d})$, $\mathrm{C}_{1}$ was level of aluminium concentration in drinking water $(\mathrm{mg} / \mathrm{L}), \mathrm{R}_{1}$ was ingestion rate $(2 \mathrm{~L} /$ day $), \mathrm{F}_{\mathrm{E}}$ was exposure frequency (day/year), $\mathrm{D}_{\mathrm{t}}$ was exposure duration (year), $\mathrm{W}_{\mathrm{B}}$ was body weight $(\mathrm{kg})$ and $\mathrm{T}_{\mathrm{AVG}}$ was average of exposure duration $(\mathrm{D} \times 365$ days/year).

\subsection{Calculation of Significant Exposure for Non-carcinogen Health Effect}

To conclude the significant exposure and overall potential for non-carcinogenic health effect posed by aluminium in drinking water, the Health Index (HI) was calculated using the following equation [17]:

$$
\text { Hazard Index }=(\mathrm{CDI}) /(\mathrm{RfD})
$$

CDI was chronic daily intake and RfD was reference dose. RfD for Aluminium is $7 \mathrm{mg} / \mathrm{kg} /$ day. [18] In cases where the non-cancer $\mathrm{HI}$ does not exceed unity $(\mathrm{HI}<1)$, it is assumed that no chronic risks are likely to occur at the site $[17,19]$.

\subsection{Statistical Analysis}

Data from questionnaire, aluminium concentration in drinking water, respondent body weight, CDI and HI of both study areas were analyzed using Statistical Package for Social Science (SPSS) version 18.0 with the significant value $(\mathrm{p}<0.05)$. Kolmogorov -Smirnov, Shapiro Wilk and Skewness tests were used to determine the normality of distribution of the interval/ratio scale variables. The data were analyzed in two stages. The first stage was univariate analysis. Bivariate analysis was then calculated to test the hypothesis, which was made to test for testing differences between two villages' study variables.

\subsection{Quality Control}

Pre-test questionnaires were performed on $10 \%$ of sample size before the start of the study on selected adults to ensure the understanding of the questions (face validity). In order to control the selection bias, matching procedure was conducted controlling for: i) source of water and ii) the usage of water filter.

\subsection{Ethical}

Approval from Medical Researcher Ethics Committee, Faculty of Medicine and Health Sciences, Universiti Putra Malaysia (UPM) was obtained. Written consent was signed before data collection commenced.
Table 1. Respondents' age, household income and duration of residence.

\begin{tabular}{|c|c|c|c|c|}
\hline \multirow{2}{*}{ Variable } & \multirow{2}{*}{$\begin{array}{c}\begin{array}{c}\text { MPL } \\
(n=50)\end{array} \\
\text { Mean } \pm \\
\text { (S.D.) }\end{array}$} & \multirow{2}{*}{$\begin{array}{c}\begin{array}{c}\text { PR } \\
(n=50)\end{array} \\
\text { Mean } \pm \\
\text { (S.D.) }\end{array}$} & \multicolumn{2}{|c|}{$\begin{array}{c}\text { Statistical } \\
\text { Test }\end{array}$} \\
\hline & & & $\begin{array}{c}\mathbf{Z} / \mathbf{t} \\
\text { Value }\end{array}$ & $\begin{array}{c}\mathbf{p} \\
\text { Value }\end{array}$ \\
\hline Age (years) & $\begin{array}{l}43.2 \pm \\
(18.68)\end{array}$ & $\begin{array}{l}44.2 \pm \\
(16.53)\end{array}$ & -0.31 & 0.756 \\
\hline $\begin{array}{l}\text { Household } \\
\text { Income } \\
\text { (RM) }\end{array}$ & $\begin{array}{l}805.6 \pm \\
(482.9)\end{array}$ & $\begin{array}{c}1065 \pm \\
(662.19)\end{array}$ & -2.26 & $0.024 *$ \\
\hline $\begin{array}{c}\text { Duration of } \\
\text { Residence } \\
\text { (years) }\end{array}$ & $\begin{array}{c}27.4 \pm \\
(19.05)\end{array}$ & $\begin{array}{l}31.86 \pm \\
(20.96)\end{array}$ & -1.12 & 0.264 \\
\hline
\end{tabular}

$\mathrm{N}=100 ;$ *Significant at $\mathrm{p}<0.05$

Table 2. Respondents' levels of education

\begin{tabular}{ccc}
\hline & $\begin{array}{c}\text { MPL } \\
\text { Levels of Education }\end{array}$ & $\begin{array}{c}\text { PR } \\
(\mathbf{n}=\mathbf{5 0})\end{array}$ \\
\cline { 2 - 3 } & Frequency (\%) & Frequency (\%) \\
\hline No Formal Education & $4(8)$ & $4(8)$ \\
Primary School & $20(40)$ & $13(26)$ \\
$\begin{array}{c}\text { Penilaian Menengah } \\
\text { Rendah (PMR) } \\
\text { Sijil Pelajaran Malaysia } \\
\quad \text { (SPM) }\end{array}$ & $6(12)$ & $5(10)$ \\
$\begin{array}{c}\text { Sijil Tinggi Pelajaran } \\
\text { Malaysia (STPM) }\end{array}$ & $9(18)$ & $21(42)$ \\
Higher Education & $3(6)$ & $3(6)$ \\
\hline
\end{tabular}

$\mathrm{N}=100$

\section{Results}

\subsection{Socio-demographic Information}

This study was conducted in M. Pt. Lubok (MPL) and Pt. Raja (PR) where respondents use treated water as their main source of drinking water. Respondents were Malay, aged between 19 to 88 years old and from 100 respondents, $69(69 \%)$ were males and the 31 (31\%) were females. Table 1 shows data regarding age, monthly household income and duration of residence while Table 2 shows respondents' education levels.

\subsection{Aluminium Levels in Drinking Water}

It was found that aluminium levels in both locations at MPL and PR ranged from $0.12 \mathrm{mg} / \mathrm{L}$ and $0.36 \mathrm{mg} / \mathrm{L}$ with a mean and standard deviation of $0.200 \mathrm{mg} / \mathrm{L}$ and 0.039 $\mathrm{mg} / \mathrm{L}$, respectively. Table 3 shows information regarding aluminium levels in drinking water in both study locations. Parametric test (t-test) was used to determine the differ 
Table 6. Chronic Daily Intake

\begin{tabular}{|c|c|c|c|c|c|c|}
\hline \multirow{2}{*}{ Variable } & \multicolumn{2}{|c|}{$\begin{array}{c}\text { MPL } \\
(n=50)\end{array}$} & \multicolumn{2}{|c|}{$\begin{array}{c}\text { PR } \\
(n=50)\end{array}$} & \multirow[b]{2}{*}{$\mathbf{t}$} & \multirow[b]{2}{*}{$\mathbf{p}$} \\
\hline & Range & $\begin{array}{l}\text { Mean } \\
\text { (S.D.) }\end{array}$ & Range & $\begin{array}{l}\text { Mean } \\
\text { (S.D.) }\end{array}$ & & \\
\hline $\begin{array}{c}\text { Chronic Daily } \\
\text { Intake } \\
\text { (mg/kg/day) }\end{array}$ & $0.00303-0.01158$ & $\begin{array}{c}0.00619 \\
( \pm 0.00164)\end{array}$ & $\begin{array}{l}0.0027- \\
0.01274\end{array}$ & $\begin{array}{c}0.00707 \\
( \pm 0.0022)\end{array}$ & -2.268 & 0.026 \\
\hline
\end{tabular}

Table 3. Aluminium Level in Drinking Water

\begin{tabular}{|c|c|c|c|c|}
\hline \multirow{2}{*}{ Variable } & $\begin{array}{c}\text { MPL } \\
(n=50)\end{array}$ & $\begin{array}{c}\text { PR } \\
(n=50)\end{array}$ & \multirow{2}{*}{$\begin{array}{c}\text { t } \\
\text { Value }\end{array}$} & \multirow{2}{*}{$\begin{array}{c}\mathbf{p} \\
\text { Value }\end{array}$} \\
\hline & $\begin{array}{c}\text { Range } \\
(\text { Mean } \pm \\
\text { S.D. }) \\
\end{array}$ & $\begin{array}{c}\text { Range } \\
\text { (Mean } \pm \\
\text { S.D.) } \\
\end{array}$ & & \\
\hline $\begin{array}{c}\text { Aluminium } \\
\text { levels } \\
(\mathrm{mg} / \mathrm{L})\end{array}$ & $\begin{array}{c}0.13-0.23 \\
(0.200 \pm \\
0.039)\end{array}$ & $\begin{array}{c}0.14-0.36 \\
(0.22 \pm \\
0.044)\end{array}$ & -0.4509 & $\begin{array}{c}\mathrm{p}< \\
0.001 *\end{array}$ \\
\hline
\end{tabular}

$\mathrm{N}=100 *$ Significant at $\mathrm{p}<0.001$

Table 4. Difference of Aluminium Levels between MPL and Malaysia Drinking Water Standard

\begin{tabular}{ccccc}
\hline & $\begin{array}{c}\text { MPL } \\
(\mathbf{n}=\mathbf{5 0})\end{array}$ & & $\begin{array}{c}\mathbf{t} \\
\text { Value }\end{array}$ & $\begin{array}{c}\mathbf{p} \\
\text { Value }\end{array}$ \\
$\begin{array}{c}\text { Mean } \\
(\mathbf{m g} / \mathbf{k g} / \mathbf{d a y})\end{array}$ & S.D. & & \\
0.2 & \pm 0.039 & 4.782 & $0.007^{*}$ \\
\hline
\end{tabular}

$\mathrm{N}=50 *$ Significant at $\mathrm{p}<0.01$

Table 5. Difference of Aluminium Levels between PR and Malaysia Drinking Water Standard

\begin{tabular}{|c|c|c|c|c|}
\hline \multirow{2}{*}{$\begin{array}{c}\begin{array}{c}\text { Pt. Raja } \\
(n=50)\end{array} \\
\text { Mean } \pm \text { S.D. }\end{array}$} & \multicolumn{2}{|c|}{$\begin{array}{c}\text { Observed Proportion } \\
\text { Value }\end{array}$} & \multirow{2}{*}{$\begin{array}{c}\mathbf{Z} \\
\text { Value }\end{array}$} & \multirow{2}{*}{$\begin{array}{c}\mathbf{p} \\
\text { Value }\end{array}$} \\
\hline & $\begin{array}{c}\text { Group } 1 \\
(\leq 0.199 \\
\text { mg/L) }\end{array}$ & $\begin{array}{c}\text { Group } 2 \\
(>0.199 \\
\mathrm{mg} / \mathrm{L})\end{array}$ & & \\
\hline $0.22 \pm 0.044$ & 0.3 & 0.7 & 0.50 & $0.007^{*}$ \\
\hline
\end{tabular}

Table 7. Hazard Index

\begin{tabular}{ccccc}
\hline \multirow{2}{*}{$\begin{array}{c}\text { Hazard } \\
\text { Index }\end{array}$} & \multicolumn{2}{c}{ MPL } & \multicolumn{2}{c}{ PR } \\
\cline { 2 - 5 } & $\begin{array}{c}\text { Frequency } \\
(\%)\end{array}$ & (Mean) & $\begin{array}{c}\text { Frequency } \\
(\%)\end{array}$ & (Mean) \\
\hline $\mathrm{HI}<1$ & $50(100)$ & $(0.00088)$ & $50(100)$ & $(0.00101)$ \\
$\mathrm{HI}>1$ & 0 & 0 & 0 & 0 \\
\hline $\mathrm{N}=100$ & & & &
\end{tabular}

ence of aluminium concentration in drinking water between these two areas. Results showed that there was significant difference of aluminium concentration in drinking water between the two study areas $(\mathrm{p}<0.05, \mathrm{Z}$ $=-0.4509)($ Table 3$)$.

\subsection{Difference of Aluminium Levels between MPL and Malaysia Drinking Water Stan- dard}

The difference in aluminium concentration in drinking water from MPL with Malaysia Drinking Water Standard was analyzed using a parametric test (one sample t-test) with reference value of $0.2 \mathrm{mg} / \mathrm{L}$. Result in Table 4 shows significant difference in aluminium concentration in drinking water from MPL with Malaysia Drinking Water Standard $(\mathrm{p}<0.05, \mathrm{t}=4.782)$.

\subsection{Difference of Aluminium Levels between PR and Malaysia Drinking Water Standard}

Non parametric test was used to analyze the difference in aluminium concentration in drinking water from PR with Malaysia Drinking Water Standard with the reference value of $0.2 \mathrm{mg} / \mathrm{L}$. From binomial test, there was significant difference $(p<0.05, z=0.50)$ between aluminium levels in drinking water at PR with the Malaysia Drinking Water Standard (Table 5).

\subsection{Chronic Daily Intake and Hazard Index}

Respondents' chronic daily intake (CDI) for both study area was calculated using the CDI equation. The variables that used in calculated CDI included aluminium concentration in water, duration of residence and body weight. Table 6 shows the Chronic Daily Intake (CDI) of respondents from both study areas. From analysis, it was found out that there was significant difference of CDI of aluminium intake between both locations $(\mathrm{p}<0.005, \mathrm{t}=$ -2.268 ). Hazard index (HI) was used to determine the heath risk of aluminium by dividing Chronic Daily Intake (CDI) with Reference Dose (RfD) of aluminium $\mathrm{RfD}(7 \mathrm{mg} / \mathrm{kg} /$ day) [18]. From the result shown in Table7, hazard index of both locations were less than 1 . 


\section{Discussion}

\subsection{Demography Data and Respondents' Back- ground}

Respondents were chosen from two different locations: M. Pt. Lubok (MPL) and Pt. Raja (PR). It was found that respondents of these two locations were not much different in terms of age, levels of education and other demographic background. Most respondents were in the range of 40 to 50 years old. With regards to gender, 69 $(69 \%)$ of them were male and $31(31 \%)$ were female. Males exceeded females due to most of the respondents were self-employed, so chances to meet the male respondents were higher than the female respondents especially when involving village people.

From the statistical analysis, it was found that the only difference between respondents from both locations was household monthly income, where MPL had a lower household monthly income compared to PR. This situation occurred probably because most of the respondents in MPL were self-employed such as farmers and this location was quite far from the main city compared to PR. However, for respondents at PR, they have a better standard of living, for example as government servants.

Variables that were similar for respondents in both locations were age and duration of residence. It was found out that through statistical analysis, respondents' age and duration of residence showed no significant difference between these two locations. Duration of residence is important because it showed how long the respondents were being exposed to aluminium in drinking water at each location.

\subsection{Difference of Aluminium Levels between Two Locations}

The design and operation of processes at water treatment plant influence the aluminium levels in the treated water that will be delivered to consumers [20]. If there is another additional treatment process such as lime softening added during aeration process for acidic raw water, this process may influence aluminium levels in treated water [20]. Consequently, aluminium levels in treated water may differ for different treatment plants. Therefore, this study did find the same conclusion in which there was significant difference of aluminium levels in drinking water between MPL and PR $(\mathrm{P}<0.05, \mathrm{Z}=-0.4509)$.

Nevertheless, this finding was similar to a previous study done in Romania, where there was a significant difference of aluminium levels in drinking water from different water treatment plants [21]. Another study in Malaysia, showed significant different of aluminium levels between two locations in the southern region of Ma- laysia [22]. Therefore, as stated in the result, the 'p' value was less than alpha set in this study (0.05), thus the null hypothesis is rejected where there is significant difference of aluminium levels in two different villages.

\subsection{Difference of Aluminium Levels between MPL and Malaysia Drinking Water Stan- dard}

From the analysis of difference test, it showed that there was significant difference between aluminium levels at the study location and standard of aluminium for drinking water $(\mathrm{p}<0.05, \mathrm{t}=4.782)$. Next, it was found out that 14 of $50(28 \%)$ water samples collected exceeded the standard aluminium levels in Malaysia, whereas in a study done in Galicia, Spain $19 \%$ of water samples collected contained aluminium levels exceeded the maximum concentration level of $0.2 \mathrm{mg} / \mathrm{L}$ [23].

Aluminium levels in drinking water vary according whether aluminium sulphate (alum) were used during water treatment. The dose of alum used depended on the properties of the raw water, turbidity, temperature and alkalinity [24]. Raw water with low turbidity often needs higher dose of alum to bring about coagulation than more turbid waters since waters of low turbidity and high colour are most difficult to treat [24]. Nevertheless, under optimal conditions, conventional method is capable of achieving a minimum aluminium levels in the treated water of around $0.03 \mathrm{mg} / \mathrm{L}$ [20].

\subsection{Difference of Aluminium Levels between PR and Malaysia Drinking Water Standard}

Aluminium levels in PR ranged between $0.14 \mathrm{mg} / \mathrm{L}$ to $0.36 \mathrm{mg} / \mathrm{L}$. From 50 samples collected, (70\%) samples exceeded the standard level $(0.2 \mathrm{mg} / \mathrm{L})$ with the highest value of $0.36 \mathrm{mg} / \mathrm{L}$. In addition, it was found that there was significant difference in aluminium levels between PR and Malaysia Drinking Water Standard. Besides that, from the year 2001 to 2005 , there occurred violations of aluminium standard where 154 water samples collected from $211(73 \%)$ samples had exceeded the Malaysian Drinking Water Standard [5].

Aluminium levels in treated water that above of 0.3 $\mathrm{mg} / \mathrm{L}$ reflect a lack of optimization in the coagulation, sedimentation and filtration stages of the conventional method [20]. According to WHO, in the coagulation process, what is important is that a correct dose be applied to the raw water as effectively as possible. This means that certain information must be known accurately, such as the dose required, amount of coagulant per unit of volume in each batch, amount of dilution water and also the dosing equipment applies the desired dose all the time [8]. 


\subsection{Difference of respondents' Chronic Daily Intake (CDI) of Aluminium Intake between the Two Locations}

From the statistical analysis, it was found out that there was significant difference of CDI of aluminium intake between both locations $(\mathrm{p}<0.005, \mathrm{t}=-2.268)$. CDI of aluminium intake for MPL was in ranged of 0.00303 $\mathrm{mg} / \mathrm{kg} /$ day to $0.01158 \mathrm{mg} / \mathrm{kg} /$ day, whereas for PR, CDI ranged from $0.0027 \mathrm{mg} / \mathrm{kg} / \mathrm{day}$ to $0.01274 \mathrm{mg} / \mathrm{kg} /$ day. This is mostly due to low aluminium levels measured in drinking water for both locations since the most contributable factor in CDI equation is aluminium levels rather than other factors such as respondents' body weight and exposure duration to aluminium in drinking water. These findings were far lower if compared to a previous study in Selangor, Malaysia, where mean of first location, KSM was $0.0516 \mathrm{mg} / \mathrm{kg} /$ day and second location, was $0.0391 \mathrm{mg} / \mathrm{kg} /$ day [25].

\subsection{Hazard Index of Aluminium Intake between the Two Locations}

The HI was used to determine the hazard risk, where, if the $\mathrm{HI}$ value was less than 1 , it indicates an unlikely potential for adverse health effects, while if the HI value was greater than 1, it indicates a concern for adverse health effects or the need for further study [19]. The result from this study was $100 \%$ for both locations showing HI lower than 1, which means that the risk was acceptable. When comparing CDI of aluminium intake between study locations with Reference Dose (RfD) which is $7 \mathrm{mg} / \mathrm{kg} /$ day, CDI of aluminium intake for both locations were far lower than RfD.

As a conclusion, this study showed that mean of aluminium levels in both locations had exceeded the Malaysian Drinking Water Standard which is $0.2 \mathrm{mg} / \mathrm{L}$. Even though the degree of difference was not significantly higher, action must be taken to reduce the aluminium levels in drinking water to similar or below the national standard. This is important to ensure the quality of water received by the consumers follow the standards put up by the health authority. Optimization of raw water process at the water treatment plant must be implemented since the conventional method is capable of achieving a very minimum aluminium levels in treated water.

\section{Acknowledgements}

The researchers wish to thank for the cooperation of the laboratory staff, academic staff for the sampling and analysis of water at the Environmental and Occupational
Health Science Unit, Department of Community Health, UPM. Give special token of appreciation to Ministry of Health, especially all management staff and health inspectors in Batu Pahat District Office Malaysia for their assistance during data collection and sampling. Lastly, not forget all respondents at Mukim Parit Lubok and Parit Raja, who were very helpful in making the study a success.

\section{References}

[1] United States Geological Surve, USA Geological Survey, National Field Manual for the Collection of Water-Quality Data, 2011. http://pubs.water.usgs.gov/twri9A/

[2] M. S. Aini, A. Fakhrul-Razi, O. Mumtazah and J. C. Meow Chen, "Malaysian Households' Drinking Water Practices: A Case Study," International Journal of Sustainable Development \& World Ecology, Vol. 14, pp. 503-505, 2007.

[3] R. L. Calderon, "The Epidemiology of Chemical Contaminants of Drinking Water," Food and Chemical Toxicology, Vol. 38, pp. S13-S20, 2000. doi:10.1016/S0278-6915(99)00133-7

[4] MOH, "Drinking Water Quality Standard Drinking Water Quality Surveillance Programme," Engineering Services Division Ministry of Health, Putrajaya, Malaysia, 2009.

[5] MOH, "Sistem Bekalan Air Loji Rawatan Air Parit Raja IV dan Sri Gading, Batu Pahat," Batu Pahat, Johor, Malaysia, 2005.

[6] D. Krewski, R. A. Yokel, E. Nieboer, D. Borchelt, J. Cohen, J. Harry, S. Kacew, J. Lindsay, A. M. Mahfouz and V. Rondeau, "Human Health Risk Assessment for Aluminium, Aluminium Oxide, and Aluminium Hydroxide," Journal of Toxicology and Environmental Health-Part B-Critical Reviews, Vol. 10, pp. 1-269, 2007. doi:10.1080/10937400701597766

[7] ATSDR, "Public Health Statement: Aluminium," Department of Health and Human Services, Public Health Service: Agency for Toxic Substances and Disease Registry (ATSDR), Atlanta, 2006.

[8] WHO, "Upgrading Water Treatment Plants," World Health Organization Publication, 2001.

[9] M. Gidding, "Aluminum," Environmental and Workplace Health Canadian Drinking Water Quality, Canada, 1998.

[10] P. T. Srinivasan, T. Viraraghavan and K. S Subramanyam, "Aluminium in Drinking Water: An Overview," Water SA, Vol. 25, pp. 47-55, 1999.

[11] V. Rondeau, D. Commenges, H. J. Acqmin-Gadda, J. F. Dartigues, "Relation Between Aluminum Concentrations in Drinking Water and Alzheimer's Disease: An 8-year Follow-up Study," American Journal of Epidemiology, Vol. 152, pp. 59-66, 2000. doi:10.1093/aje/152.1.59

[12] C. Janson, et al., "Insomnia is More Common among Subjects Living in Damp Buildings," Occupational and Environmental Medicine, Vol. 62, pp. 113-118, 2005. doi:10.1136/oem.2003.011379 
[13] EPA, “A Guide to Health Risk Assessment," California Office of Environmental Health Hazard Assessment, California, 2001.

[14] P. Kavcar, et al., "A Health Risk Assessment for Exposure to Trace Metals via Drinking Water Ingestion Pathway," International Journal of Hygiene and Environmental Health, Vol. 212, pp. 216-227, 2009. doi:10.1016/j.ijheh.2008.05.002

[15] MOH, "National Standard for Drinking Water Quality," Engineering Sevices Division, Ministry of Health Malaysia, Putrajaya, 2004.

[16] PerkinElmer, "Water and Environmental Analysis According to US EPA Regulations Using the Lambda 25/35/45 UV/Vis Spectrophotometers," 2006.

[17] USEPA, "Risk Assessment Guidance for Superfund. Vol. I. Human Health Evaluation Manual. Part A. Interim Final," Office of Emergency and Remedial Response, U. S. Environmental Protection Agency, Washington, DC, 1989.

[18] FAO and WHO, "Aluminum: Evaluation of Certain Food Additives and Contaminants, 32," Report of the Joint FAO/WHO Expert Committee on Food Additives, WHO, Geneva, 1989, pp. 28-31.

[19] USGS., U. S. Geological Survey, National Field Manual for the Collection of Water-Quality Data. http://pubs.water.usgs.gov/twri9A/

[20] Health Canada, "Aluminum [Technical docment-Chemical/Ph- ysical Parameters]," 2008, p. 3. http://www.hc-sc.gc.ca/ewh-semt/pubs/water-eau/alumin um/aluminum-aluminium-eng.php

[21] D. Diaconu, et al., "Aluminum Concentration in Drinking
Water from Moldova Territory, Romania," Ovidius University Annals of Chemistry, Vol. 20, pp. 115-118, 2009.

[22] A. Nora, "Kepekatan Aluminium Dalam Air Minum dan Penilaian Risiko Kesihatan di dua petempatan di Johor," Unievrsiti Putra Malaysia, Selangor, 2003.

[23] D. A. Rubinos, et al., "Aluminium Contents Indrinking Water from Public Water Supplies of Galicia (Northwest Spain)," The Fourth Inter-Celtic Colloquium on Hydrology and Management of Water Resources, Portugal, 2005.

[24] NHRMC, "Australian Drinking Water Guidelines," National Water Quality Management Strategy. National Resource Management Ministerial Council (NHMRC), Australia, 2004.

[25] A. Azmir, "Kepekatan Aluminium di dalam air minum dan Penilaian Risiko Kesihatan di dua buah petempatan di Selangor," BSc. Environmental and Occupational Health, Department of Community Health, Universiti Putra Malaysia, Selangor, 2003.

[26] Mohd Sham Shaharuddin, Yusoff Mohd Kamil, Yaziz Mohammed Ismail, Ramli Mohammad Firuz, I. Syazwan Aizat and Abdullah Mohd Yunus, "Fluoride Concentration in Malaysian Drinking Water," American-Eurasian Journal of Agricultural \& Environmental Sciences, Vol. 6, No. 4, pp. 417-420, 2009.

[27] M. S. Shaharuddin, M. N. Kidahus, S. Sumarlan, Y. M. Kamil and Y. M. Ismail et al. "Dental Fluorosis (DF) and Its Relationship With Fluoride Levels in Drinking Water in Three States in Malaysia," Research Journal of Medical Sciences, Vol. 4, No. 1, pp. 20-24, 2010. doi: $10.3923 /$ rjmsci.2010.20.24 